\title{
Permanent education and matrix support in primary health care: family health routine
}

Educação permanente e apoio matricial na atenção primária à saúde: cotidiano da saúde da família

Educación permanente y apoyo matricial en la atención primaria de salud: cotidiano de la salud de la familia

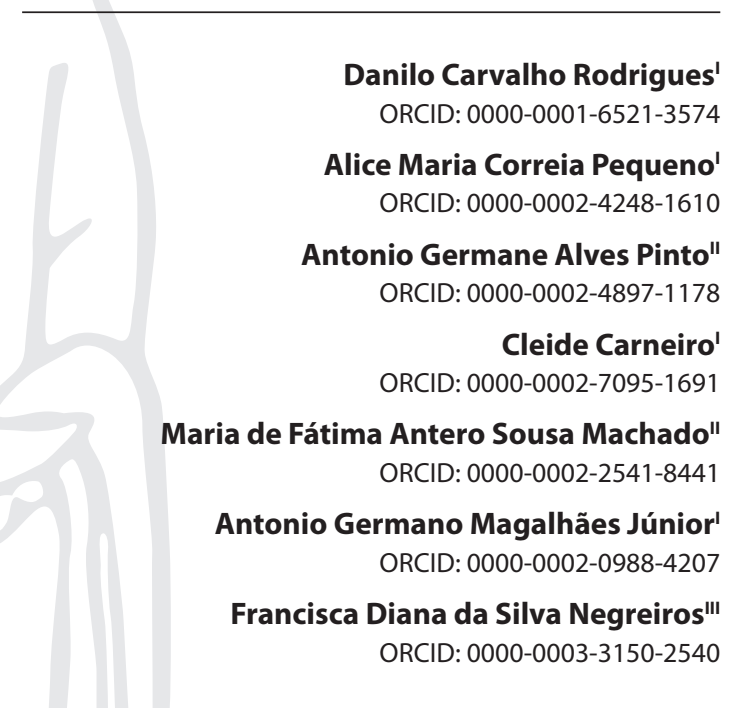

'Universidade Estadual do Ceará. Fortaleza, Ceará, Brazil. "Universidade Regional do Cariri. Crato, Ceará, Brazil. "' Universidade Federal do Ceará, Hospital Universitário Walter Cantídio. Fortaleza, Ceará, Brazil.

How to cite this article: Rodrigues DC, Pequeno AMC, Pinto AGA, Carneiro C, Machado MFAS, Magalhães Jr AG, et al. Permanent education and matrix support in primary health care: family health routine. Rev Bras Enferm. 2020;73(6): e20190076. doi: http://dx.doi.org/10.1590/0034-7167-2019-0076

Corresponding author: Francisca Diana da Silva Negreiros E-mail: negreiros.diana@gmail.com

EDITOR IN CHIEF: Dulce Barbosa ASSOCIATE EDITOR: Hugo Fernandes

Submission: 06-18-2019

Approval: 02-25-2020

\section{ABSTRACT}

Objective: To analyze the understanding of the professionals working on the Family Health Support by about permanent education and matrix support in the daily routine of primary health care. Methods: Descriptive research with a qualitative approach. Data were collected through semi-structured interviews with the participation of 19 professionals from different backgrounds. The results were organized based on Thematic Content Analysis. Results: Thematic categories emerged from the analysis: Permanent Health Education: knowledge and daily activities; Matrix support as a premise of Permanent Health Education; The principle of integrality as the foundation of the supporting teams; Conditions of praxis in the promotion of Permanent Health Education. Final Considerations: The study evidenced that professionals experience their routines within the service and that the sharing of knowledge to transform the reality of users and the territory is based on matrix support and integrality. However, they face structural difficulties in carrying out actions.

Descriptors: Education, Continuing; Primary Health Care; Family Health; Health Promotion; Integrality in Health.

\section{RESUMO}

Objetivo: Analisar a compreensão dos profissionais do Núcleo de Apoio à Saúde da Família acerca da educação permanente e apoio matricial no cotidiano da atenção primária à saúde. Métodos: Pesquisa descritiva com abordagem qualitativa. Os dados foram coletados por meio de entrevista semiestruturada com participação de 19 profissionais de distintas formações. Os resultados foram organizados com base na Análise de Conteúdo Temática. Resultados: Emergiram da análise as categorias temáticas: Educação Permanente em Saúde: saberes e fazeres cotidianos; O matriciamento como premissa de Educação Permanente em Saúde; O princípio da integralidade como fundamento das equipes apoiadoras; Condicionantes da práxis na promoção da Educação Permanente em Saúde. Considerações finais: Evidencia-se que os profissionais vivenciam suas rotinas dentro do serviço e que o compartilhamento dos conhecimentos para a transformação da realidade dos usuários e do território é pautado no apoio matricial e integralidade, embora se deparem com dificuldades estruturais para realização de ações.

Descritores: Educação Permanente; Atenção Primária à Saúde; Saúde da Família; Promoção da Saúde; Integralidade em Saúde.

\section{RESUMEN}

Objetivo: Analizar la comprensión de los profesionales del Núcleo de Apoyo a la Salud de la Familia acerca de la educación permanente y apoyo matricial en el cotidiano de la atención primaria de salud. Métodos: Investigación descriptiva con abordaje cualitativa. Los datos han sido cogidos por medio de entrevista semiestructurada con participación de 19 profesionales de distintas formaciones. Los resultados han sido organizados con base en el Análisis de Contenido Temático. Resultados: Surgieron del análisis las categorías temáticas: Educación Permanente en Salud: saberes y quehaceres cotidianos; El apoyo matricial como premisa de Educación Permanente en Salud; El principio de la integralidad como fundamento de los equipos apoyadores; Condicionantes de la praxis en la promoción de la Educación Permanente en Salud. Consideraciones finales: Se ha evidenciado que los profesionales viven sus rutinas dentro del servicio y que la coparticipación de los conocimientos para la transformación de la realidad de los usuarios y del territorio ha pautado en el apoyo matricial e integralidad, sin embargo se deparen con dificultades estructurales para realización de acciones.

Descriptores: Educación Continua; Atención Primaria de Salud; Salud de la Familia; Promoción de la Salud; Integralidad en Salud. 


\section{INTRODUCTION}

Currently, the international discussion based on issues related to work and health education includes reflection on policies, regulations, and operations relevant to teaching, training and professional practices, emphasizing the need to link training with the competences required by work, the use of new teaching methodologies and the incorporation of health information, education and communication technologies. This global issue appears among the commitments made by countries in the face of the agenda ${ }^{(1)}$.

In the national scenario, the Unified Health System (SUS Sistema Único de Saúde), having its structured bases in the health reform, has the constitutional competence to order the training of professionals in the area. In this sense, Brazilian public health policies, now based on SUS guidelines, have demonstrated an important role to trigger changes in the education process of health professionals, of which the political landmark was the creation, by the Ministry of Health, of the Permanent Health Education National Policy ${ }^{(2)}$.

In this perspective, Permanent Health Education (PHE) is as an intense educational line with potentialities linked to mechanisms and themes that enable professionals to reflect on work processes, self-management, institutional change and transformation of practices in service through the proposal for learning how to learn, working in a team, building daily lives and constituting themselves as an object of individual, collective and institutional learning to reach the strategic goals of SUS ${ }^{(2)}$. Its proposal seeks to develop the educational processes of professionals in a decentralized, ascending, and transdisciplinary way.

With regard to primary health care, PHE actions are essential and are part of the teams' work process, and should be incorporated into the daily routine of services (through meetings, territorial forums, among others) and based on a significant educational program that provides greater competence of analysis and intervention and autonomy for the development of transformative practices by family health teams. Also, PHE must be part of the teams' day-to-day activities, and it must have space guaranteed in the workload of the workers and include the qualification of all the multidisciplinary team, as well as the managers ${ }^{(3)}$.

This fact prompted reflection on the daily work in health was the need for the interconnectivity of physical, psychological, and social well-being, leading professionals inserted in this context to adopt the biopsychosocial approach in their actions on patients. For a long time, this approach was at odds with current health models, as it was based merely on a model of biomedical care in which pathologies were diagnosed and treated with a limited focus on the patients' disease. Also, in the past, mental and physical health conditions were usually treated separately, resulting in a fragmentation of health care ${ }^{(4)}$.

Considering these aspects and aiming at strengthening primary health care and focusing on the health territories needs to be faced by primary care teams, the Family Health Support (NASF - Núcleos de Apoio à Saúde da Família) were created in 2008 by the Ministry of Health, as another effort to restructure the health work process. The NASF aims to support the Family Health Strategy (FHS) in the health service network and to expand its scope and resolution. After approval and publication by the
Ministry of Health of Ordinance 2,436, of September 21, 2017, which gave rise to the new version of the National Primary Care Policy, the NASF changed its name to the Extended Family Health and Primary Care Center (NASF-AB - Núcleo Ampliado de Saúde da Família e Atenção Básica) ${ }^{(5)}$.

NASF-AB teams must have their work guided by the theoretical and methodological framework of matrix support. This framework, also called matrix support, is a way of providing health care in a shared way with a view to comprehensive and resolvable care through interdisciplinary work. Such support can increase the power of thinking, inventing, (inter) acting, and caring ${ }^{(5)}$.

Therefore, the NASF-AB must contribute both to the ongoing education process of the support teams, in the perspective of expanding care and job qualification, as well as in the constitution of matrix support as an important work tool and a privileged mechanism for permanent health education, since it bases on interprofessionality, working in networks, acting in a defined territory, sharing knowledge and co-management. Furthermore, it also has an educational and training component when building spaces for discussion, knowledge exchange, and reflection for professional practice(6).

However, the principle of integrality of SUS still presents challenges to be overcome, despite the advances in this public policy. It is important to observe the dimension of its definition, involving axes related to the following fields: promotion and prevention actions, the guarantee of assistance at the three levels of complexity, articulation of work on healthcare, and overall health recovery for users and their families. Therefore, integrality emphasizes the construction of policies that consider the current health needs of the individuals on whom they act ${ }^{(7)}$.

Given the above, with regard to health training and in-service training, we questioned: How professionals of the NASF-AB understand permanent education and matrix support in the daily routine of primary health care?

In this sense, this research may give rise to reflections and discussions related to actions developed by NASF-AB professionals based on matrix support and integrality of care, contributing to the (re) orientation of their health promotion practices and advancing the improvement of PHE actions.

\section{OBJECTIVE}

To analyze the understanding of the professionals working on the Family Health Support center about permanent education and matrix support in the daily routine of primary health care.

\section{METHODS}

\section{Ethical aspects}

The research was approved by the Research Ethics Committee of the State University of Ceará and followed the ethical principles recommended by Resolution 466/12 of the National Health Council (Conselho Nacional de Saúde), which regulates the guidelines and standards of research with human being ${ }^{(8)}$. Data collection was carried out with clarification to participants about the research objectives, proposed methodology, risks and 
benefits, and signing of the Free and Informed Consent Form. The representation of the participants' names was expressed by the letter I of "interviewee" followed by the number, according to the order of the interview (E1, E2 ... E19), guaranteeing confidentiality and anonymity throughout the research process.

\section{Theoretical-methodological framework and type of study}

It is a descriptive and exploratory research with a qualitative approach that used Thematic Content Analysis as a theoretical framework for data analysis ${ }^{(9)}$. This research is an excerpt from the dissertation entitled "Knowledge and practices of professionals from the Family Health Support Center of Iguatu-CE in the light of Permanent Health Education," from the Professional Master's Degree in Health Education, from the State University of Ceará. The study followed the list of criteria included in the Consolidated criteria for reporting qualitative research (COREQ) ${ }^{(10)}$, which guides qualitative research.

\section{Methodological procedures}

\section{Study scenario}

The study was carried out in the municipality of Iguatu-CE, located in the Center-South region of the state of Ceará, approximately 380 $\mathrm{km}$ away from its capital Fortaleza. Iguatu is on the list of the 299 most populous municipalities in Brazil and the nine most populous in Ceará. It has the 10th gross domestic product of Ceará, with a human development index of 0.677 , ranking 10th in the state's human development index. It is the city of the Center-South of the state that has more undergraduate courses. In the field of health, the municipality includes Primary Care / Basic Care with 25 teams of Family Health Strategy, being three teams of the NASF.

\section{Data source}

The study participants were professionals from NASF-AB in the city of Iguatu-CE, among them: nurses (6), dentists (3), physiotherapists (3), nutritionists (3), pharmacists (3) and physical education professionals (3), totaling 21 professionals. The inclusion criteria established for the participants were: to have at least six months of work experience in the team, as this length of work in service provides a more accurate experience about the problems presented in the daily work; be practicing and regularly registered as a civil servant at the municipal health department, and participate as a member of the NASF multiprofessional team. The exclusion criterion established was: the professionals must be away from their activities due to illness, vacation, or on leave during the study period. We invited the 21 eligible professionals to collaborate with the research, and all accepted. However, we excluded two nurses because they were on maternity leave during the data collection period, so 19 was the number of participants.

\section{Data collection and organization}

Data collection took place from June to August 2016. Semistructured interviews were carried out containing a script with subjective questions. The data collection instrument was developed by the researcher and subjected to a pre-test with health professionals who did not participate in the study, and suggestions for improvement were accepted. We contacted the research participants at their workplaces and scheduled the interviews in advance according to their availability. The interview took place in a room reserved for that purpose, located at the NASF, to guarantee the confidentiality of the information. We requested participants' permission to record the speeches, clarifying the scientific purpose and its forms of use, using a digital voice recording device, with an average duration of 30 minutes. The interviews were later transcribed in full by the researcher, guaranteeing the reliability of the reports explained by the participants. Field notes were made in a diary with a description of the interviewees' expressions/behaviors in order to better understand the phenomenon studied.

\section{Data Analysis}

After transcribing the interviews in full, the data treatment followed the Thematic Content Analysis, according to the stages of pre-analysis, exploration of the material, and treatment of the results ${ }^{(11)}$. In the pre-analysis, the transcribed material was organized; then, there was a fluctuating and exhaustive reading of the speeches, defining the corpus of the work. With a view to the exploration of the material, we refined the data to provide a better understanding of the meaning of the text, based on the relationship between empirical data, objectives, research assumptions, allowing proximity to the meanings expressed in the words and the unveiling of the meaning cores. We framed, categorized, and described the corpus. Relevant literature correlated the analyses.

For Minayo ${ }^{(9)}$, data analysis seeks to provide theoretical and methodological answers based on which the data collected in the interview seek to achieve three objectives: overcoming uncertainty, enriching reading, and integrating findings.

\section{RESULTS}

The speeches of the participants raised three thematic categories, namely: 1)Permanent Health Education: knowledge and daily activities; 2) Matrix support as a premise of Permanent Health Education; 3) The principle of integrality as the foundation of the supporting teams; 4 ) Conditions of praxis in the promotion of Permanent Health Education.

\section{Permanent Health Education: knowledge and daily activities}

We found that professionals, in their speeches, recognize the assumptions of PHS in the work process as a space for sharing knowledge and practices, exchanges in which knowledge is given and received. They identify actions such as activities in groups with professionals from the Family Health Strategy, Community Health Agents (CHA) and activities with users, construction of therapeutic projects, educational interventions, and home visits.

We do permanent education as much as we receive. It is when we perform permanent activities, we usually perform it, especially about the NASF, and about what the NASF is, for professionals, mainly for community health agents and the population. But we 
also perform it about professional categories, about nutrition, occupational therapy, psychology, and physiotherapy. And we also receive it as we are a School of Public Health and coordination. (I10)

Concerning the production of common sense and meaning as learning in collective work, this occurs due to the technicalpedagogical dimension of work with professionals of the Family Health Strategy and related teams, during the elaboration of interventions and mediation of conflicts and in various situations involving joint agreement.

As for the technical-assistance dimension of the work with an emphasis on educational health actions, NASF professionals reported dialogue circles as an educational means of preventing health problems and raising awareness of health practices with the groups of users of health units, such as express the speeches:

We try to offer the courses. Specifically, among the teams that our territory covers, the teams of basic health units, and therein come the guidelines, lectures, experiences, according to the demands that are placed. (E8)

We are continually doing permanent education in the health unit. Every two months, we sit down with community health agents, and also with the NASF team, to plan dialogue circles with pregnant women, with hypertensive patients, we also make groups on the issue of smoking, which we are guiding these patients on the importance of overcoming addiction. (I19)

In addition to individual specialized care, they highlighted home visits with family health teams. Such activities promote the identification of problems in the territory and allow approximation and knowledge of the living and health conditions of the families under their responsibility and are conceived by the interviewees as permanent education actions.

I think it is a bias of permanent education since I am there contributing to it so that she can reflect on their work process $[\mathrm{CHA}]$, which in this case is more the family, home visits, and the referrals for us, in this case ... So I think I may be contributing to a reflection in this case, with the Family Health Teams as a whole. (14)

In the view of the participants of this study, the work aimed at the realization of PHE is a process in continuous construction, in which difficulties and challenges are favorable aspects for the interrelation of knowledge. Different areas should discuss conflict situations, encouraging discussion, even if permeated by divergences and convergences.

\section{Matrix support as a premise of Permanent Health Education}

The matrix of the NASF as a premise of PHE aims to provide support to the linked teams, as well as to establish the co-management of responsibilities, as a work methodology that ensures the specialized defense, both at the assistance and technicalpedagogical level, through the collective construction of shared knowledge among primary care professionals.

Permanent Health Education in groups created by the Family Health Strategy by NASF. The NASF matrix support to the FHS, as well as the NASF teams themselves. Mainly the discussion of work processes, discussion of cases, home visits, planning of the work process between teams. (I5)

The speeches of the interviewees reveal the understanding of the importance of team integration and matrix support to the work carried out along with the mental health teams, bringing a new look at the way of producing health, in a construction shared between the different specialties and professions.

An example of permanent education is matrix support. Matrix support practice occurs along with the mental health personnel once a month. I think it is also a very important characteristic of permanent education; not only management brings a subject to talk about, but management also will not bring a subject. And when it comes to matrix support, we discuss specific questions about mental health, because Basic Care ... you know? It goes hand in hand with mental health. (118)

Well, we have a powerful practice that is considered as permanent education, which is matrix support, which happens together with Mental Health. In addition to matrix support, we still have meetings mainly with health agents, as we are NASF residents. So every month, we also have a unit in Fortaleza, we have meetings, all meetings are very didactic, very different, varied themes, so for us, the strongest ones are still those. (I16)

NASF teams cited matrix support according to the needs of the community, considering the epidemiological context of the territories. The look on the singularities of the territory discloses prioritizing actions, defining permanent education activities for groups and interprofessional articulation with the family health team:

For us to be developing permanent education, it needs to be in accordance with our reality, of each territory, because each territory is different. (14)

We have matrix support practices, so there are conversations with the CHA; between the team, education between the team, CHA, and matrix support are the most used in our territory. The educational activities that we do in the community, with the groups that we also do, that the group does not only do that topic ... we do permanent education with users as well. (117)

\section{The principle of integrality as the foundation of support teams}

In the words of the interviewed professionals, the principle of integrality underlies the team's actions as a strength of the work itself. They reveal practices aimed at integrality, in a process that makes collective work viable from significant strategies that are in line with the principles of SUS.

We are always available here. What community health agents demand or what Family Health teams demand. We want to discuss this case... oh, we want you to talk about benefits, or about nutrition, physiotherapy, we want guidance on healthy eating, for us to share with our users. (14)

Professionals refer to the potential of teamwork aiming comprehensive care, which brings together the performance 
of different professionals and their knowledge to promote the user's health. They also allow the emergence of difficulties encountered that refer to the dimension of the territory and the fact that not all professionals carry out Permanent Health Education actions.

The main potential would be to try to resolve the weaknesses, but, also, the integration of the team, where we articulate the work according to the problems of the territory, availability, and the desire to change a reality that exists today in relation to healthcare. The weaknesses, the first thing is the scope of the territory for our NASF, right? Which I think is very large. (I7)

I think the team is a potential, the professionals who are part of that team. Although we have all these difficulties, we try to produce and do our best. There is the issue of the car, which was something that we did not have, and now we have. I see that, on the days that we have it, it helps a lot. (I11)

Potentiality is the support of the team, at the same time that it becomes a weakness. We have a complete team, but also not everyone on the team is part of permanent education. And also the ignorance of users that becomes a weakness. (117)

Integrality is an organizational premise of work in health, of a collective and multidisciplinary nature, which arises in order to expand the diagnosis of the community's health demands; it requires openness and dialogue and takes into account the different knowledge and perceptions of healthcare needs. Therefore, the dimension of the word "integrality" refers to the collectivity of the multidisciplinary universe, the interaction between theory and practice, constituting the value of the joint construction of the different fields of knowledge.

It is worth mentioning that, in the perception of professionals in this study, PHE finds its foundation in the daily construction of work, always referring to unfinished work. It is from there that its potentialities emerge, that is, from the understanding that it is a process in constant construction.

\section{Conditions of the praxis of professionals in the promotion of Permanent Health Education}

In the analysis of the conditions for the practice of NASF professionals in promoting $\mathrm{PHE}$, the almost unanimity of them explained the term "lack of resources," referring to investments applied to the purchase of materials, material equipment, among other means, for the realization of PHE.

The weaknesses, we can consider: lack of work material, lack of planning space, lack of mobilization, as other teams, which do not mobilize the group participants, lack of material, transportation, and in short, they are diverse. (110)

It is the service as a whole, weaknesses, lack of resources, like, we have too much, and it causes great anguish in us, the anguish it is, like, in our daily lives. It is noticeable in all professionals because it is an issue, we plan, but to execute it, we need a resource, and the resource we have is only the human resource, right? And very, very little material, expedient material. (I11)
Among the various problems reported by the participants in this study, the professionals' dissatisfaction with the participation and encouragement of management stands out, which is often omitted from work. They also pointed out the lack of support and knowledge of the latter in the planning and execution of PHE actions with professionals and, sometimes, the lack of appreciation of the actions. Even so, even though there is an impasse in the encounter and the dialogue, $\mathrm{PHE}$ is adopted and practiced in the daily work of NASF, as shown in the statements:

\begin{abstract}
About managers, I think it is the very lack of knowledge of the importance, many times; they do not have this knowledge of the importance! About what is permanent education. Concerning the other teams, there is the same difficulty in terms of time, due to the different assignments of each service, so it ends up being in the background, it is always put in the background. And in relation to users, I think they end up losing when we are making this exchange. Making this question permanent and continuous, they end up losing in the quality of the service. (115)
\end{abstract}

In the speeches of the professionals, a dissatisfaction was manifested, which carries a weakening aspect, referred to as the lack of interest and demotivation of some teams in carrying out the work focused on PHE actions, also: lack of interest and commitment of some professionals, excessive demand, accumulated service and lack of time to promote PHE in daily health practices.

\section{DISCUSSION}

According to the perceptions of NASF professionals, PHE is a strategy that encompasses work processes and is based on collaborative work. This conception is similar to that found in results of an integrative review, in which PHE work process, in the practice scenario, is an object of transformation, starting from professionals' critical reflection about what is happening in the daily services and seeking solutions together with the team to the problems encountered ${ }^{(11)}$.

In the testimonies, there is an exchange of practices and knowledge between the FHS, NASF and community teams during the work process through dialogue circles, courses and training in groups to raise awareness about preventing or delaying comorbidities associated with diseases, thus enabling greater socialization between the health team and users. A qualitative study carried out in Minas Gerais found similar data. The study found a positive perception of users concerning NASF practices and, thus, demonstrated the potential of the groups' actions, expressed in welcoming, bonding, and therapy practicing. The horizontal didactic model used in such practices enables the incorporation of knowledge, making the individual an active agent and responsible for changing habits. Thus, the study noticed that joint meetings are spaces for learning, coexistence, and socialization permanently ${ }^{(12)}$.

The aspects verified in the technical-assistance dimension mentioned by the professionals are supported by educational interventions in health that imply integration with the community in the services, making their participation in decisions, determinations, and work proposals, with a view to health promotion ${ }^{(13)}$.

In relation to the NASF matrix as a premise of $\mathrm{PHE}$, professionals showed a positioning consistent with the proposed objective of 
matrix support, which consists of integrating primary care and specialized service and, therefore, can provide an exchange of knowledge in a more comprehensive and less fragmented, decentralizing care. Thus, NASF professionals would be guiding and building together with other professionals, working collectively with other sectors and equipment of primary care. Strengths in consolidating the practice of matrix support are the flexibility to form support teams surpassing the NASF-AB format with the ability to organize issues permeated by the real condition and needs of the territory; guarantee of spaces for promoting permanent actions of matrix support; possibility of shared construction of work principles; use of multiple tools in contact with supported teams and users; and promotion of collective means that make it possible to analyze the actions taken. The weak points in the development of assistance are the reduced workload and a large number of supported teams ${ }^{(14)}$.

This study showed that matrix support in mental health is one of the potent actions performed by NASF-AB. These findings corroborate research carried out in the state of Santa Catarina, which considered as an advance and an indicator of quality in health the acceptance of the demand for mental health in primary care. Still, the study pointed out that the different possibilities of NASF-AB performance go through experiences from participation in the regulation, evaluation, and reduction in the waiting list for specialties to the total fusion of the NASF-AB team's identity as that of a reference service, which has been more advanced in mental health matrix support ${ }^{(15)}$.

In this context, the institutional performance of NASF-AB professionals is linked to the specialist center, which works based on their specific competence, the interdisciplinary requirement, and also the necessary articulation between services in order to arise and exist coordination of assistance by primary care through the PHE. Thus, we understand that the work of NASF-AB can and should be seen as a source of new forms of intervention, which are expressed in mediating spaces between the cores of knowledge and practice of its professionals (specialists) and the cores and field of knowledge - which must be highlighted and respected - of generalists. This view expands the potential of their integral contributions to the qualification of assistance while intensifying its educating and supportive effect ${ }^{(15)}$.

It is noteworthy that the FHS consists of a powerful space for the consolidation of PHE by carrying out shared practices in teams with the use of different technologies for the care of users, for having an inductive role in the interdisciplinary work of the team, in building a bond between the team and users and the reformulation of traditional knowledge and health practice ${ }^{(16)}$. Among these benefits, considered results of $\mathrm{PHE}$, aimed at better training of professionals and awareness of users, the authors cite the reduction in the waiting list for care, the strengthening of the bond with the community and the introduction of preventive actions in the FHS, as well as the modification of management practices and health care.

The matrix created since 2006, to strengthen the national model of health in defense of life, provides strategic health actions based on the fundamental needs of the population, linking sanitary measures. The matrix supporter facing the Family Health teams listens and probes the real health needs and difficulties of the reference territories. Thus, matrix support is the locus for planning, organizing, reflecting, and restructuring shared service spaces to share knowledge among the various actors and overcome the segmentation of work resulting from specialties ${ }^{(17)}$.

Thus, the matrix logic that guides the NASF-AB performance went through a long construction before being integrated as a methodological tool in public health policy. Soon after the emergence of SUS, matrix support appears as a reflection of the daily processes of work on health, as an indispensable demand for guiding work in primary care ${ }^{(18)}$.

Integrality is a theoretical foundation of $\mathrm{PHE}$, thus seeking to overcome the fragmented character of health care teaching and services in the perception of NASF professionals. Such conception is supported by an integrative literature review, which presents the teaching-service integration as a strategy for professional improvement, as it connects informative content and motivation through the collective construction of knowledge ${ }^{(11)}$.

Thus, for PHE in the context of SUS to be legitimized as an educational movement and policy and its practices and initiatives are consolidated by health workers in the scenario of practices in primary care in Brazil, managers must work with health professionals, professionals be trained to orient these initiatives, as well as better articulation between service, educational institutions, and popular participation. It is believed that the training and development of health workers should take place in a thoughtful, participatory and continuous way, focused on local needs, services, and people, strengthening the link between managers, educational institutions, health professionals and the population, improving the quality of the health system ${ }^{(11)}$.

It is important to note that the NASF-AB system requires a broader view of professionals on health actions and, often, it encourages them to a performance that goes beyond the centered and curative view. In this way, the work process focused on comprehensive care and, based on the focus on the health needs of the territory materializes, encompassing clinical-assistance and technical-pedagogical actions based on matrix support aimed at the community ${ }^{(17)}$.

Regarding the resources needed to exercise NASF actions, in addition to the high number of teams to work with in the matrix support practive and the dimension of the territories, these aspects corroborate studies that attest to the precarious working conditions represented by the lack of physical space and materials, technological devices, media and transportation ${ }^{(19-20)}$. Concerning the implementation of the PHE policy in Rio Grande, whose obstacles point to a lack of resources or more productive investments, difficulties are perceived in the operationalization of the flow for the execution between the project and its fulfillment ${ }^{(21)}$.

The professionals' dissatisfaction with the management's participation and incentive and the lack of support and knowledge of it in the planning and execution of PHE actions with the professionals mentioned in this study converge with an investigation that points out weaknesses in the work for the practice of $\mathrm{PHE}^{(22)}$.

The performance of the centers requires better qualification of their professionals and reassessment of work processes, in addition to investment in the structure so that this important strategy can achieve matrix support and integrated management of care ${ }^{(23)}$. It is necessary to consider the innovative aspect of 
matrix support as a genuinely Brazilian construction ${ }^{(24)}$, since in the international scenario, like Canada and the United Kingdom, authors refer that the discussion centers on the exchange of knowledge between professionals and in shared care, especially in the care of chronic diseases.

\section{Study Limitations}

The limitation of this study was that it did not include the other professionals of the Family Health Strategy or the municipal health manager, which would allow a more accurate analysis of the convergences and divergences pointed out in the work process. However, the results of the research enabled the immersion in the phenomenon that brought to light the perceptions of NASF professionals about issues subsumed in their daily lives, in the context of Permanent Health Education.

\section{Contributions to nursing, health, or public policy fields}

The research made it possible to unveil the daily actions performed by NASF professionals, with a view to matrix support and integrality of care. The multiprofessional look at their practices can contribute to the (re) orientation of the work process, advancing towards the improvement of actions of permanent health education. Reflections on the praxis articulated to primary health care are an essential strategy to overcome the challenges of interdisciplinarity and integrality, with repercussions on the population's health.

The discourse on how activities should be carried out is present in the professionals' ideas, but health care practices show that there is a considerable distance between knowledge and practice. Thus, the NASF-AB clinical-assistance support is developed based on the population's demands for specialized care, in contrast to the guideline of serving as support while offering shared care, expanded clinic, performs co-management, and shares responsibilities with the FHS.

\section{FINAL CONSIDERATIONS}

When analyzing the knowledge and actions in the daily life of NASF professionals about Permanent Health Education, we noticed that they have different conceptions about PHE. There is a perception that brings out the actions carried out in context with the needs of the territory and how the construction of work shared with primary care professionals configures it.

Regarding the practice of $\mathrm{PHE}$, professionals cited matrix support as a set of educational practices designed to promote opportunities in the work process based on mutual support and the acquisition of new experiences that professionals exchange, with emphasis on mental health actions.

The study highlighted the actions of Permanent Health Education as a pillar for carrying out the work process. It expresses the conjecture with which NASF professionals experience their routines within the health service, their daily practices, and the sharing of knowledge to transform the reality of users and the territory, based on matrix support and integrality.

There are also gaps related to work processes, such as practices that transmit and reproduce information, poor applicability of resources linked to the lack of planning and management incentives. Also, the study reveals aspects of the interaction between professionals and the users' lack of knowledge about work based on PHE.

The findings of this study can contribute to configuring the actions of PHE in the NASF as practices of interaction and dialogue capable of producing meaning for users, health workers and managers, in order to strengthen primary care and the Unified Health System.

\section{REFERENCES}

1. World Health Organization (WHO). Global strategy on human resources for health: Workforce 2030. [Internet]. 2016[cited 2019 Dec 20]. Available from: https://apps.who.int/iris/bitstream/handle/10665/250368/9789241511131-eng.pdf?sequence=1

2. Ministério da Saúde (BR). Secretaria de Gestão do Trabalho e da Educação na Saúde. Departamento de Gestão da Educação na Saúde. Política Nacional de Educação Permanente em Saúde: o que se tem produzido para o seu fortalecimento? [Internet]. Brasília: Ministério da Saúde. 2018[cited 2019 Dec 20]. Available from: http://bvsms.saude.gov.br/bvs/publicacoes/politica_nacional_educacao_permanente_ saude_fortalecimento.pdf

3. Ministério da Saúde (BR). Gabinete do Ministro. Portaria n 2.436, de 21 de setembro de 2017. Aprova a Política Nacional de Atenção Básica, estabelecendo a revisão de diretrizes para a organização da Atenção Básica, no âmbito do Sistema Único de Saúde (SUS) [Internet]. Diário Oficial da União. 2017 [cited 2019 Dec 23]. Available from: http://www.saude.df.gov.br/wp-conteudo/uploads/2018/04/Portaria-n\%C2\%BA2436-2017-Minist\%C3\%A9rio-da-Sa\%C3\%BAde-Aprova-a-Pol\%C3\%ADtica-Nacional-de-Aten\%C3\%A7\%C3\%A3o-B\%C3\%A1sica..pdf

4. Mann CC, Golden JH, Cronk NJ, Gale JK, Hogan T, Washington KT. Social workers as behavioral health consultants in the primary care clinic. Health Soc Work. 2016;41(3):196-200. doi: 10.1093/hsw/hlw027

5. Ministério da Saúde (BR). Núcleo Ampliado de Saúde da Família e Atenção Básica (Nasf AB). Trajetória da estratégia, organização do processo de trabalho e perspectivas do Ministério da Saúde[Internet]. Brasília: Ministério da Saúde. 2018 [cited 2019 Dec 23]. Available from: http://189.28.128.100/dab/docs/portaldab/documentos/geral/Apresentacao_Nasf.pdf

6. Oliveira MM, Campos GWS. Formação para o Apoio Matricial: percepção dos profissionais sobre processos de formação. Physis. 2017;27(2):187-206. doi: 10.1590/s0103-73312017000200002

7. Chaves $L A$, Jorge $A O$, Cherchiglia $M L$, Reis IA, Santos $M A C$, Santos $A F$ et al. Integração da atenção básica à rede assistencial: análise de componentes da avaliação externa do PMAQ-AB. Cad. Saúde Pública. 2018;34(2):e00201515. doi: 10.1590/0102-311x00201515 
Permanent education and matrix support in primary health care: family health routine Rodrigues DC, Pequeno AMC, Pinto AGA, Carneiro C, Machado MFAS, Magalhães Jr AG, et al.

8. Ministério da Saúde (BR). Conselho Nacional de Saúde. Comissão Nacional de Ética em Pesquisa. Resolução n 466, de 12 de dezembro de 2012: diretrizes e normas regulamentadoras de pesquisa envolvendo seres humanos [Internet]. Brasília; 2012 [cited 2018 Nov 17]. Available from: http://conselho.saude.gov.br/resolucoes/2012/Reso466.pdf

9. Minayo MCS. O desafio do conhecimento: pesquisa qualitativa em saúde. 13a ed. São Paulo: Hucitec; 2013.

10. Tong A, Sainsbury P, Craig J. Consolidated criteria for reporting qualitative research (COREQ): a 32-item checklist for interviews and focus groups. Int J Qual Health Care. 2007;19(6):349-57. doi: 10.1093/intqhc/mzm042

11. Ferreira L, Barbosa JSA, Esposti CDD, Cruz MM. Permanent Health Education in primary care: an integrative review of literature. Saúde Debate. 2019;43(120):223-39. doi: 10.1590/0103-1104201912017

12. Fernandes ETP, Souza MNL, Rodrigues SM. Práticas de grupo do Núcleo de Apoio à Saúde da Família: perspectiva do usuário. Physis. 2019;29(1):e290115. doi: 10.1590/s0103-73312019290115

13. Rodrigues DC, Pequeno AMC, Pinto AG, Carneiro C, Machado MFAS. Saberes e práticas dos profissionais do Núcleo de Apoio à Saúde da Família à luz da educação permanente em saúde. Atas CIAIQ2018. Investig Qualit Saúde[Internet]. 2018[cited 2018 Nov 17];2:809-18. Available from: https://proceedings.ciaiq.org/index.php/ciaiq2018/article/view/1851/1801

14. Castro CP, Oliveira MM, Campos GWS. Matrix Support in the SUS of Campinas: how an inter-professional practice has developed and consolidated in the health network. Ciênc Saúde Coletiva. 2016;21(5):1625-36. doi: 10.1590/1413-81232015215.19302015

15. Vendruscolo C, Ferraz F, Tesser CD, Trindade LL. Family health support center: an intersection between primary and secondary health care. Texto Contexto Enferm. 2019;28:e20170560. doi: 10.1590/1980-265x-tce-2017-0560

16. Soratto J, Pires DEP, Dornelles S, et al. Family health strategy: a technological innovation in health. Texto Contexto Enferm. 2015;24(2):584592. doi: 10.1590/0104-07072015001572014

17. Silva LJCA, Araújo ACV, Vasconcelos NL, Paiva CBN, Pires CA. The contribution of the matrix supporter in overcoming the traditional psychiatric mode. Psicol Estudo. 2019;24:e44107. doi: 10.4025/psicolestud.v24i0.44107

18. Maffissoni AL, Silva KJ, Vendruscolo C, Trindade LL, Metelski FK. Matrix role of the Primary Care Extended Centers: an integrative review of the literature. Saúde Debate. 2018;42(119):1012-1023. doi: 10.1590/0103-1104201811918

19. Aguiar CB, Costa NMSC. Formação e atuação de nutricionistas dos Núcleos de Apoio à Saúde da Família. Rev Nutr. 2015;28(2):207-16. doi: 10.1590/1415-52732015000200009

20. Gonçalves RMA, Lancman S, Sznelwar LI, Cordone NG, Barros JO. Estudo do trabalho em Núcleos de Apoio à Saúde da Família (NASF), São Paulo, Brasil. Rev Bras Saúde Ocup. 2015;40(131):59-74. doi: 10.1590/0303-7657000078013

21. Daniel HB, Sandri JVA, Grillo LP. Implantação de política de educação permanente em saúde no Rio Grande do Sul. Trab Educ Saúde. 2015;12(3):541-62. doi: 10.1590/1981-7746-sip00007

22. Gomes LB, Barbosa MG, Ferla AA. A educação permanente em saúde: conexões para a produção de saberes e práticas. Porto Alegre: Rede Unida [Internet]. 2016[cited 2019 Jan 10]. Available from: http://www.redegovernocolaborativo.org.br/publicacoes/livros/ EPSeasRedesColaborativas.pdf

23. Santos SFS, Benedetti TRB, Medeiros TF, Freitas CLR, Sousa TF, Costa JLR. The work of physical education professionals in Family Health Support Centers (NASF): a national survey. Rev Bras Cineantropom Desemp Hum. 2015;17(6):693-703. doi: 10.5007/1980-0037.2015v17n6p693

24. Bispo Jr JP, Moreira DC. Educação permanente e apoio matricial: formação, vivências e práticas dos profissionais dos Núcleos de Apoio à Saúde da Família e das equipes apoiadas. Cad Saúde Pública. 2017;33(9):e00108116. doi: 10.1590/0102-311×00108116 